ISSN: $1412-4734$

E-ISSN: 2407-8646

Volume 18, Number 2, 2018

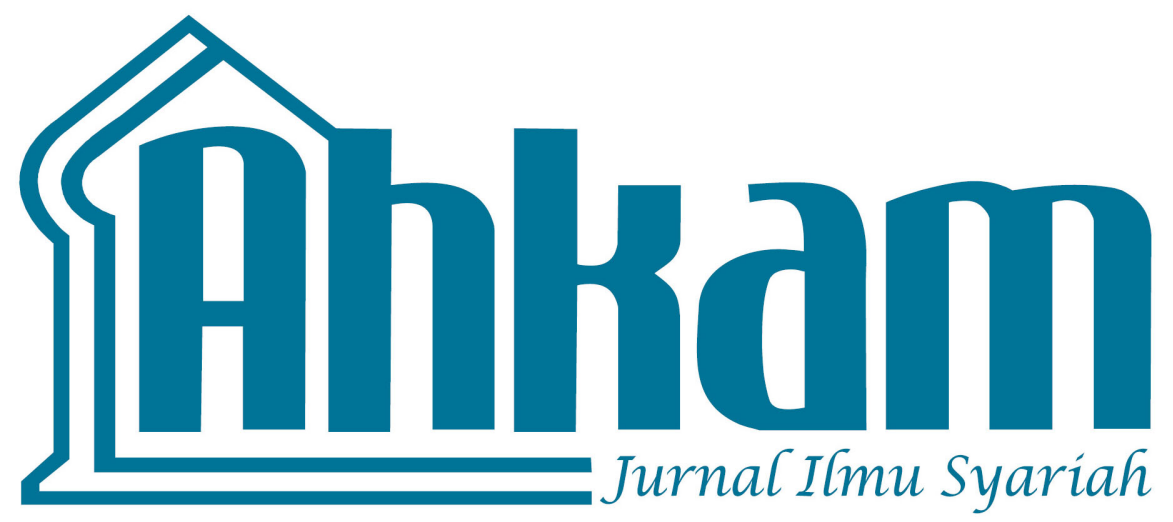

* Arifuddin Muda Harahap

Rules on Wage Standard to Improve Workers' Living Needs in the Perspective of Maqasid Al-Shari'ah

* M. IkHsan TanggoK

Circumcision Law in Christianity and Islam

* Abdul Rohman Zulfikar Alfaroug \& Nurhasanah The Positivisation of National Sharia Board Fatwa About Mudaraba into Financial Service Authority Regulation

* Muhamad Isna Wahyudi

Women Dealing With the Law in Religious Courts

* Arif Hidayatullah \& Anita Priantina

Toward Zakat Management Integration in Indonesia: Problems and Solution

* Muhammad Adil dan Muhamad Harun

Fiqh Melayu Nusantara in the Palembang Darussalam Sultanate Period

* Sugiri Permana

Implications of Hazairin and Munawir Sjadzali Thoughts in Establishment of Islamic Inheritance in Indonesia 


\section{Mhliam}

Volume 18, Number 2, 2018

\section{EDITOR-IN-CHIEF}

Khamami Zada

\section{EDITORS}

Fathudin

Maman R Hakim

Windy Triana

Nur Hidayah

Ahmad Bahtiar

\section{INTERNATIONAL EDITORIAL BOARD}

Tim Lindsey (University of Melbourne Australia)

Nadirsyah Hosen (Monash University Australia)

Ahmad Hidayat Buang (Universiti Malaya Malaysia)

Raihanah Azahari (University Malay Malaysia)

Mark Elwen Cammack (Southwestern University)

Razeen Sappideen (University of Western Sydney)

Carolyn Sappideen (University of Western Sydney)

Nik Ahmad Kamal bin Nik Mahmod (International Islamic Universiti Malaysia)

Ahmad Tholabi Kharlie (UIN Syarif Hidayatullah Jakarta)

Muhammad Atho Mudzhar (UIN Syarif Hidayatullah Jakarta)

Masykuri Abdillah (UIN Syarif Hidayatullah Jakarta)

Muhammad Amin Suma (UIN Syarif Hidayatullah Jakarta)

M. Arsykal Salim GP (UIN Syarif Hidayatullah Jakarta)

Asep Saepudin Jahar (UIN Syarif Hidayatullah Jakarta)

ASSISTANT TO THE EDITORS

Kamal F. Musa

Erwin Hikmatiar

ENGLISH LANGUAGE ADVISOR

Bradley Holland

Umi Kulsum

ARABIC LANGUAGE ADVISOR

Amany Burhanudin Lubis

AHKAM has been accredited based on the determination of Director General of Research Reinforcement and Development, Research, and Technology Ministry of Higher Education of Republic of Indonesia, No. 36/a/E/KPT/2016 (valid until 2021). 
AHKAM Jurnal Ilmu Syariah (ISSN: 1412-4734) is a periodical scientific journal published by Faculty of Sharia and Law of Syarif Hidayatullah State Islamic University Jakarta in collaboration with Indonesian Scientist and Sharia Scholar Association (HISSI). This journal specifically examines the science of sharia and obtains to present various results of current and eminence scientific research. The administrators receive articles as contributions Sharia and Islamic law disciplines from scientists, scholars, professionals, and researchers to be published and disseminated.

\section{EDITORIAL OFFICE:}

Fakultas Syariah dan Hukum UIN Syarif Hidayatullah Jakarta

Jl. Ir. H. Juanda 95 Ciputat, Jakarta 15412

Telp. (+62-21) 74711537, Faks. (+62-21) 7491821

Website: http://journal.uinjkt.ac.id/index.php/ahkam/index

E-mail: Jurnal.ahkam@uinjkt.ac.id 


\section{TABle of Contents}

251 Arifuddin Muda Harahap

Rules on Wage Standard to Improve Workers' Living Needs in the Perspective of Maqasid Al-Shari'ah

265 M. IkHSAN TANGgOK

Circumcision Law in Christianity and Islam

285 Abdul Rohman Zulfikar Alfaroug \& Nurhasanah The Positivisation of National Sharia Board Fatwa About Mudaraba into Financial Service Authority Regulation

305 Muhamad Isna Wahyudi

Women Dealing With the Law in Religious Courts

321 Arif Hidayatullah \& Anita Priantina

Toward Zakat Management Integration in Indonesia:

Problems and Solution

347 Muhammad Adil \& Muhamad Harun

Figh Melayu Nusantara in the Palembang Darussalam Sultanate Period 
375 Sugiri Permana

Implications of Hazairin and Munawir Sjadzali Thoughts in Establishment of Islamic Inheritance in Indonesia

395 RifQi QOWIyul ImAn

The Competence of Religious Court in Indonesia and

Syahadah Istifadhah (Testimonium De Auditu) in Case of Itsbat Waqf

417 Mustapa Khamal Rokan \& Kama Rusdiana Configuration of Costomary Law Related to Economy (Economic Adat Law Study in North Sumatera, Indonesia)

433 Yayan Sopyan \& Muhammad Shofwan Nidzami Nyabek Toloh Marriage Proposal Tradition in Madurese Culture: A Review of The Sociology of Islamic Law

453 Nuryani \& M. Musyafa

Linguistic Review on Marriage Age Regulation

463 Wetria Fauzi

Regulation of Sharia Insurance After the Enactment of Law No. 40 of 2014 Concerning Insurance 


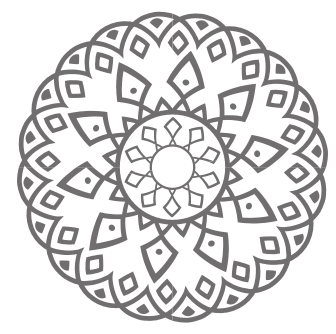

\title{
Rules on Wage Standard to Improve Workers' Living Needs in the Perspective of MaQAsid Al-Shari'aH
}

\author{
Arifuddin Muda Harahap
}

\begin{abstract}
Abstrak: Komponen kebutuhan hidup yang dijadikan acuan dalam penetapan upah minimum di Indonesia telah mengalami banyak perubahan. Hal ini terjadi karena menyesuaikan perkembangan kebutuhan. Dalam Islam, ada 5 unsur pokok kebutuhan manusia yang harus dipenuhi atau yang dikenal dengan istilah maqashid al-syariah. Kelima unsur pokok maqashid al-syariah ini terbagi mejadi 3 kategori yakni daruriyyah, hajjiyah, dan tahsiniyyah. Artikel ini mengkaji bagaimana komponen kebutuhan hidup dalam regulasi upah minimum perspektif maqashid al-syariah. Artikel ini menyimpulkan bahwa dalam penentuan upah minimum harus diperhatikan tingkatan kebutuhan hidup saat ini. Sebagian besar komponen Kebutuhan Hidup Layak (KHL) ada pada wilayah daruriyyah dan hajjiyah, sedikit sekali yang tergolong tahsiniyyah. Penambahan kuota komponen serta peningkatan kualitas komponen menjadi bukti bahwa adanya perhatian terhadap tingkatan kebutuhan dimulai dari daruriyyah kemudian hajjiyah baru disusul yang tahsiniyyah. Perubahan ini menunjukkan adanya perubahan hukum sesuai dengan perkembangan situasi.
\end{abstract}

Kata kunci: upah, kebutuhan hidup layak, maqashid al-syariah. 
Abstract: The components of living needs that become the reference in determining the minimum wage in Indonesia have changed four times. These changes have occurred to adjust the development of what are regarded as necessities. There are necessities that at first considered less critical, but then become important. In Islam, there are five essential elements of human needs, known as maqasid al-shariah. These necessities are divided into three categories: daruriyya, hajiyya, and tahsiniyya. This article examines how the component of living necessities according to the concept of maqasid al shariah is applied in the minimum wage regulation. This article argues that the determination of minimum wage standard has considered the current standard of living. Most of the components of Decent Living Needs (DLN) include in the area of daruriyya and hajjiya, and only a few are in the area of tahsiniyya. The addition and improvement of the components of needs become evidence for the consideration of the level of needs, from daruriyya to hajiyya, and then tabsiniyya. This changes show the change of law in line with current development.

Keywords: wage, decent living, maqashid al-syariah

$$
\begin{aligned}
& \text { ملخص: لقد تم تعديل مكونات احتياجات الحياة التي تكون دليلا في إثبات الحد الأدني } \\
& \text { للأجور أربع مرات. يحدث هذا التعديل بسبب تكيّف تطوّر الاحتياجات يعني ما كانت }
\end{aligned}
$$

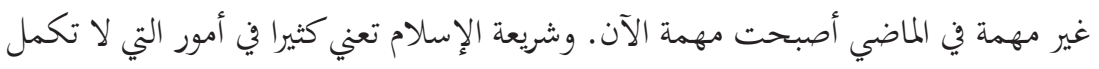

$$
\begin{aligned}
& \text { الحياة إلا بها وعبر الفقهاء هذه الأمور بالمقاصد الشرعية. تقسم هذه المقاصد إلي المقاصد } \\
& \text { الضرورية والمقاصد الحاجية والمقاصد التحسينية. تستهدف هذا البحث في تحليل موقف }
\end{aligned}
$$

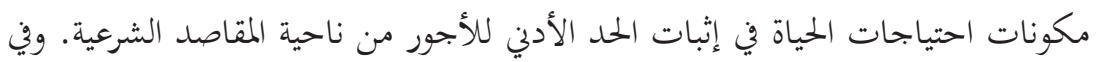

$$
\begin{aligned}
& \text { النهاية تلخص من هذا البحث أن تطور احتياجات الحياة التي هي أصل في إثبات الحد }
\end{aligned}
$$

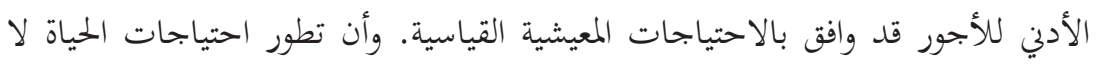

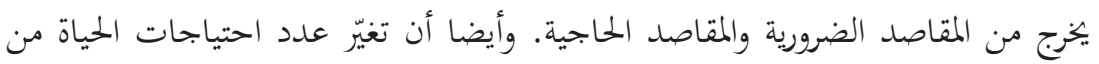

$$
\begin{aligned}
& \text { حين إلى حين دليل على وجود العناية التامة نهو مستوى الاحتياجات, بلدءا من المقاصد } \\
& \text { الضرورية ثم يليها المقاصد الحاجية وتأتي المقاصد التحسينية في الأخير. فهذا يدل على ألى أن } \\
& \text { الأحكام تدور مع علتها } \\
& \text { الكلمات المفتاحية: الأجور، الحلكم، المقاصد الشرعية }
\end{aligned}
$$




\section{Introduction}

Allah creates human in the best form to carry out the duty of Khilafah on earth as a devotion to Allah. As His vicegerents on earth, human beings are given the mandate to empower the whole universe for the welfare of all beings on the earth. There are two missions of Khilafah: vertical and horizontal missions. While the vertical mission is to worship God; the horizontal ones is to maintain the prosperity of the world. Allah Almighty created human as a zoon politicon. This means that every human needs other to share benefits. This can be done through marriage, trading/ ijara, legal treatment, social actions, land cultivation, agricultural affairs, etc. These activities can gather and unite human beings, and make them neighbors, partners and families (Al-Jurjawi, 2003: 206).

In life, a human being cannot escape from social competition. Too much dealing with such competition makes human unable to produce matters to support their life. Moreover, it is human nature to have desires that often lead to badness, ambitiousness, and harm. This is why Allah makes rules in muamala (social interaction), to regulate human's interaction so that one cannot take others' rights unrightfully. Through this muamala, human life will be on the right path; there will be no neglected rights; and there will be benefit share among human beings (Al-Jurjawi, 2003: 16).

Welfare cannot be separated from economic matters, because of the fulfilment of economic needs is the sign of human welfare. To be able to meet the living necessities, human needs to have a job to get wages. This is considered a noble activity in the teaching of Islam (Chaudhry, 2012: 187). Wages are the right of workers. Apart from the wages, workers are also entitled to social security (Zaeni Asyhadie, 2008: 74-86).

Wages are the source of income to meet the workers' needs and reflect job satisfaction. For employers, wages are part of production costs. Consequently, the costs need to be optimized to increase productivity and work ethics. Meanwhile, the government sees the wages as a mean to fulfil a decent life for the workers and their families; to increase worker productivities, and to increase consumption or purchasing power. To ensure the fulfilment of workers' rights, the government should make rules on wages. 


\section{Conceptualization of Wages: A Literature Review}

Wage in Arabic is often called ajrun/ajran which means giving rewards/wages. The term ajran contains two meanings: reward for work and reward. The term of wage refers to money that is paid in return of services and energy spent for certain works. Wage is granted as remuneration or compensation received by the workers because of their efforts in doing some works for those who hold a status of the employer. In this regard, Afzalur Rahman states that wages are the price of labor (work) paid for his services in production (Rahman, 1995: 361).

Sadono Soekirno defines wages as: "payments earned from various forms of services provided by labors to employers." (Sadono Sukirno, 2005: 350). T. Gilarso interprets wages: "as a reward for the production of human labor, which includes wages, honoraria, overtime payment, allowances, etc." (Gilarso, 2003: 211).

According to article 1 of the Government Regulation No. 78 of 2015 on Wages, wages are the right of workers received and expressed in the form of money in return from employers to workers stipulated and paid under an employment agreement, or legislation. This includes allowances for workers/laborers and their families for work and / or services that have been or will be done.

Similarly, according to Law No. 13 of 2003 on Employer, wages are the rights of workers/laborers that are received and expressed in the form of money in return from employers to workers determined and paid under an employment agreement, or legislation, including allowances for workers or laborers and their families for a work or their services.

In addition, several terms are often used to denote wage, namely compensation and rewards. In general, economists equate those three terms. However, in modern management, terms of rewards and compensation are more widely used (Jusmaliani, 2011: 116-127).

Based on the above discussion, it can be concluded that wages refer to something in the form of money or other things that commonly used as a reward or remuneration, or as a replacement for services from work that has been issued by employers to the workers or laborers.

\section{Legal Resources and Wage Determination}

Wage system in a country is based on the philosophy or economic system of the country. In Indonesia, each region determines their own 
wage standard. Wage standard determination considers the standard of needs; Consumer Price Index (CPI); and the capability, development, and sustainability of enterprise. Wage standards applied in certain regions depend on the labor market condition, the rate of economic development and per capita income. Necessities become the priority in determining the wage standard for workers. At the same time, the wage standard also considers DLN, and productivity and economic growth.

The needs in this discussion refer the Decent Living Needs (DLN), in which its components are regulated by the Ministry of Manpower. The component of needs that becomes the basis in determining the minimum wage standard has progressed. This progress is in line with the development in labors' living needs. The Decree of the Minister of Manpower No. 17 of 2005 mentions that the DLN consists of 46 items. In 2012, this decree was amended by the Decree of the Minister of Manpower and Transmigration of the Republic of Indonesia (Permenakertrans RI) Number 13 of 2012. This new regulation adds fourteen more items in the DLN. The changes in the components of DLN is based on the development of workers' necessities as mandated by Article 89 Paragraph (2) of Law Number 13 of 2003 on Manpower. With regards to DLN, the Article 88 paragraph (1) affirms that: "Every worker has the right to earn an income that fulfils a decent living for humanity."

The desire of laborers to have decent life is in accordance with the concept of state law and welfare of Pancasila in the 1945 Constitution. This means that the state supposes the harmony between the government and the people based on the principle of congeniality; the proportional functional relationship among state authorities; and the settlement of any disputes with deliberation, while courts as the last means; and the emphasize on the balance between human rights and responsibility (Syaifuddin, 2012: 2835).

Pertaining to wage policy, the government does not only consider the importance of wage for workers to improve their welfare but also regards other aspects. Appropriate wages should be based on a particular criterion. The clear criterion will enable the government to provide the rationality of wage determination. Substantive justice criteria for workers in the law on wage is to fulfil the primary, secondary, saving and social necessities. These have become workers' demand in every $1^{\text {st }}$ May Labor Day rally in Indonesia. In 2013, similar demands were 
expressed by workers in various cities in Indonesia. For hundred thousand workers in Indonesia, the demand for decent wages and better welfare has become the main issue during Labor Day rallies.

In order to achieve substantive justice for labors, it is necessary to reformulate the existing labor regulation. This is to answer the issues related to the legal aspect with regards to the wage standards to create better social welfare in the future.

\section{The Substance of Law in the Application of Wages}

Workers, in general, associate the wage with the amount (of money), whereas employers associate wage with productivity. This notion has become a problem because the demand for high wages has not been supported by high level of productivity due to the inadequate level of education and skills. Different demands from those parties have caused a dilemma for the government as a part of the tripartite to respond to them. The government needs to intervene to harmonize the existing industrial relations (Suryandono, 2014: 99).

According to Law No. 13 of 2003 on Manpower, Article 1 point 30, "a wage is the right of the worker/labor that is received and expressed in the form of money as remuneration from the entrepreneur or the employer to workers/ labourer, whose amount is determined and paid according to a work agreement, consensus, or laws and regulations, including allowances for the worker/ labourer and their family for a job and or service that has been performed or will be performed the right of workers".

Based on the 1945 Constitution, a wage must meet a decent living for humanity. Thus the fulfilment of fair wages for livelihood and humanity is a constitutional concept of wages in Indonesia. The Law No. 13 of 2003 on Manpower interprets wage as the basic rights of the workers to be met by employers. If the employer does not pay the workers' wages, they violate human rights, and it is considered a criminal offence. The concept of wage in Indonesia today has shifted from civil rights to a criminal violation against basic rights.

Wage payment, in general, considers workers' ability reflected in their productivity. The government intervenes because it is essential to align the wages that meet the decent living for humanity with the achievement of work productivity. Factors to be considered in this 
attempts are (1) workers' living necessities; (2) social disparity; (3) work performance; (4) the value of humanity and self-esteem.

Government policy on wages is triggered by conflict of interest between the employers and the workers. The main issues of wages include (1) low wages for small workers; (2) gaps between the lowest and highest gap; (3) wage components variables; (4) unclear connectivity between wages and productivity.

Small workers feel the impact of low wages, but the labor inspectors find it hard to detect it to ensure the implementation of minimum wage standard. Among formal workers, it is easier to identify the inappropriate wages; however, it is otherwise among the informal workers due to the absence of a report from the community or the workers. Meanwhile, the gap between the lowest and highest standard of wage potentially triggers social jealousy. Also, the wage payment in the form of wage components is still confusing workers when it is associated with minimum wage policy. Because of the lack of socialization, workers poorly understand the notion that the wage increases based on performance appraisal.

The government has issued a policy on minimum wage determination, or now called Minimum Wage. However, there are still some regulations that are not consistent. There has been a vertical inconsistency in the regulation of minimum wage. The protection of wage for workers in the Article 27 Paragraph (2) of the 1945 Constitution states that every citizen has the right to work and livelihood that is suitable for humanity. The Article 28D Paragraph (2) of the 1945 Constitution mentions that everyone has the right to work and receive fair and reasonable remuneration and treatment in the employment relationship.

The fair and decent remuneration in the employment relationship is reflected in the decent income for humanity (Article 88 paragraph (1) of Law No. 13 of 2003). A wage is defined as the right of workers to be received and expressed in the form of money in return of employers to workers stipulated and paid under an employment agreement, agreement or legislation including allowances for workers and their families work and/or service that has been or will be done (Article 1 Sub-Article 30 of Law No 13 of 2003).

The implementing regulation neglects this provision. The minimum 
wage amount should depend on DLN. Meanwhile, DLN is the standard of needs for a labor/ single labor to be able to live decently in one month. (Article 1 number 1 Minister of Manpower Decree No. 13 of 2012 on Components and Implementation of Stages of Achievement of Decent Living Needs (DLN). This vertical inconsistency results in the insufficient wages received by laborers and their families.

If the rule of law contradicts the universal legal theory, it is likely that there will be a violation of its philosophy. A fair wage for workers/ laborers cannot be achieved. The mismanagement of minimum wage in the level of dogmatic, legal theory and legal philosophy leads to new problems in the aspects of life.

The law that neglects legal theory and philosophy may result in a false assumption about the value of law. Law is understood partially as legal certainty, not the substance of justice. Bismar Siregar sees this as a mistake in legal education in Indonesia, (Antonius Sudirman), 2007: 119). The error should promptly be corrected, and the role of legal scholarship becomes significant. Legal experts, lawyers, law reviewers and law enforcers should regard the law as an open system.

\section{Reformulation of Wage Regulation}

There is a need to reformulate the wage-related articles in the Manpower Act. The reformulation of this wage issue needs to consider changes, either by adding, reducing or incorporating foreign law in the Manpower Act. The reformulation of the law cannot be separated from the context of legal reform. The emergence of a moral spirit in the current legal wage is due to the blunt implementation of the positive law (Labor Law).

There has been negligence of a wage system based on minimum wage standard. This is to avoid the workers to demand their rights and obtain decent wages. Lawsuits on wage focus on demand for the increase in minimum wage standard, not on the fulfilment of a decent salary. The call for the reformulation of this law is because workers and their family have received the insufficient Minimum Income Revenue (MIR).

Article 88 of the Labor Act provides the principle of fair remuneration and regulates the MIR. In the practice of wage payment, employers only pay the MIR and avoid the "increase of MIR" in the 
following year, which means they avoid the legal certainty. The decent wage in Article 88 turns out to be unclear in its description.

To achieve a decent standard of wages, Article 88 (1) should be reformulated by adding supporting points explaining the decent wage standard. With regards to the effectiveness of labor act, Kamala Sankaran states:

"The labor act, which regulates work and a decent income, is a review of the effectiveness of labor act in protecting workers in developing countries. There has been a large number of workers outside the scope of de jure or de facto labor laws (informal) around the world, as a result of changes in production and work patterns. The weakening role of national state regulation in the field of social economy today is the result of globalization. Strangely globalization in the socio-economic, political and ideological dimensions, is considered a major determinant and challenge. The implications of this development are that the labor act is a merely debatable subject within the academic community" (Sankaran, 2007: 6).

A decent wage should become a standard in the exemplary wage. Therefore, companies should be able to afford decent wages as determined by the Labor Act. The question then, why do employers not pay their employees with decent wages? The answer is that: it is sufficient for the entrepreneurs to pay the minimum wage, considering that the Labor Act justifies the minimum wage payment for the workers. If so, the Labor Act violates the 1945 Constitution. Consequently, Article 88 of the Labor Act and the Labor Act as a whole must be declared null and void (not applicable).

\section{Maqasid Al-Shari'ab as Indicator of Fair Living Needs}

At this time, Muslims face problems in life as a result of the progress of civilization. These problems, which emerge with its variety and complexity, lead to the emergence of legal issues among the ummah (Muslim society). The complexity of the issues in the modern times demands elasticity and flexibility in providing solutions to the problems (Arief, 2002: 200).

Moreover, there has been a clear picture that: "verily the nas (revelation) has ended, while occurrences never end" (Zahrah, 1989: 16). The emergence of discoveries due to the advancement of science and technology has also resulted in shifting of the perspective; forming 
a thinking flow that brings logical consequences and creating a new norm in people's lives.

The progress of science and technology and human civilization should not be confronted with the nas (Quran and hadith). Steps to be done is finding solutions through ijtihad. One of the primary methods of developing Islamic law is maqasid al-shariah, which is the purpose of the establishment of Islamic law. Because of the importance of maqasid al-shariah, the Islamic legal theorists make it as one of the considerations for mujtahid in performing ijtihad. The core of the maqasid concept is to realize the good and avoid the bad or create the benefits and reject the madarat (Mu'allim and Yusdani, 1999: 52). This notion that is in line with the core of the maqasid al-shariah is maslaha because the formulation of Islamic law should aim at creating maslaha.

Ash-Shatibi, from the Malikiyya, was the one who systematically discussed maqasid in his book Al-Muwaffaqat. He explicitly says that God's ultimate purpose in the establishment of His law is to create benefits for human life, in the world and hereafter. Therefore, taklif in the field of law should lead to the realization of the purpose of the law. According to him, maslahat maintains the five principles, namely religion, soul, intellect, offspring, and wealth. Al-Qarafi adds one more principle, which is to maintain honor and dignity (Rochman, 2001: 103).

Ash-Shathibi stated that the main purpose of maqasid al-shariah is to safeguard and fight for three categories necessities. The first is daruriyya or urgent or emergency necessities. In this category, there are five matters to be considered, namely maintaining religion, soul, mind, dignity, offspring, and property. If the daruriyyah has not been met, it will threaten the salvation of human beings in the world and the hereafter. (A. Djazuli, 2003): 397). The second is hajiyya, which means secondary necessities. If this kind of need is not fulfilled, it will not threaten human beings' salvation but will create difficulties for them. To eliminate the difficulties, Islam offers rukhsa (remission) that is the law to lighten the burden, so that the law can be implemented without depressed and restrained feelings. The third is tabsiniyya which means to complementary necessities. If this kind of need is not met, then it will not threaten human existence nor cause difficulties. (Yusuf al-Qardhawi, 1999: 79)

The notion of the maqasid al-shari'a, as affirmed by Abd al-Wahab Khallaf, is a very important tool to understand the Qur'an and Sunnah 
and resolve contradictions. Another important purpose of maqasid al-shariah is to establish the law for matters that are, because of the language, not accommodated by the Quran and Sunna (Effendi, Zein, 2004: 237).

Maqasid al-shariah is used as an analytical tool to determine the standard of human necessities. In this study, the author uses the order of maqasid al-shariah proposed by Imam Haramayn such as daruriyya, hajiyya and tabsiniyya. With regards to the element of maqasid al-shariah, the author uses Ash-Shatiby concept of maqasid al-shariah, which are to maintain religion (din), life (nafs), mind ('aql), offspring (nasb), and property $(m a l)$. The author uses the concept of maqasid al-shariah as the analytical tool, as is maintained by the predecessors that reasons can be used for matters that are not explicitly explained by the nas.

In an attempt to determine the DLN component, al-Qarafi proposes the notion of fath zarai (opening up the meaning) in order to achieve maqasid al-sharia. This concept of maqashid al shariah is at least able to bridge between the haves and the needy. The orders in maqashid al shariah are intertwined. The shift in the orders may happen depending on the situation.

The shifting of maqasid al shariah orders is in accordance with the idea of Izz ibn Abd al-Salam and Ibn Qayyim, saying that the changes in law happen by circumstances. In this context, the circumstances mean situation, place, time, social condition, intention and customs. Reason plays an active role in changing the law with the help of rational science. This is because maqasid al-shariah is an idea based on a comprehensive, open, hierarchically interdependent, and multi-dimensional purposes.

In this case, work and wages are related to the notion of maintaining the property. By working, someone expects to get prosperity in financial terms. Whereas according to the theory of necessities of maqasid alshariah, to achieve prosperity one should meet the five main elements of maqasid al-shariah. Therefore, this article aims at examining to what extent wages contribute to the life protection and support other aspects of the maqasid al-shariah. In this regards, the reason is used in determining the composition of necessities, because the nas has a little explanation on the issue. At the same time, there is also a need to consider justice and appropriateness in determining remuneration in order to accommodate the needs of the society. 
First, the compensation needs to be based on the principle of justice. It does not mean that everything to be shared equally. Justice needs to be interconnected with sacrifice (input) and income (output). The higher the sacrifice, the higher the expected income. Second, there is a need to consider the element of appropriateness. The achieve this appropriateness; a company can refer to the practice in other companies, or refer to the government regulations of the minimum wage standard, and minimum necessities. Comparing other companies' standard wage will enable the company to maintain "External Consistency". If the salary offered by the company is too small compared to other companies, then this may result in the difficulties to hire labors. Therefore, job evaluation is needed to meet both internal and external consistency (Martoyo, 1990: 104).

Islam sees the relationship between wages and moral concepts, while the West does not. Islam sees not only worldly materials but also beyond the materials. In Islam, wage consists of spiritual (hereafter) dimension called a reward. The similarity of Islam and West conception of wage is in the notion of justice, and the adequacy. In Islam adequacy are related to clothing, food, and housing. Additionally, one should not harm others by reducing their rights. This means never to pay someone lower than the usual wage standard.

In line with the current development and pressure to improve minimum wage standard, the government revised the component of DLN by issuing the Minister of Manpower Decree No. 13 of 2012 concerning the Components and Implementation of the Stages in Achieving Decent Living Needs. Previously, there was only four group of necessity. With the use of DLN, currently, there are seven group of necessities, consisting of food and drink; clothing; housing; education; health; transportation; recreation; and saving. Since 2005, this component standard is used ever since. In 2012, there was an increase in the number of component items from 46 to 60 .

The above explanation illustrates that DLN used currently is the development of the previous version. The 2012 version of DLN covers all existing components. Therefore, to analyze the element of living necessities according to maqasid al-shariah, it is sufficient to consider the 2012 version of DLN.

The changes and development of DLN indicate that the previous version considered the most crucial components. After that, in the next 
version, there is an increasing number of components, which are missing in the earlier version. The addition is done by considering the current development. Furthermore, the first version consists only matters related to darurriya, while the next version includes hajiyya and tabsiniyya. Apart from addition, there is also a change in the component to adapt to the current situation. This change illustrates the change of law in line with the change of circumstances. This is in accordance with the concept of maslaha as proposed by al-Tufi and Ibn Qayyim al-Jawziya.

\section{Conclusion}

This paper concludes, first, the growth of living necessities that is used as the guidance in determining minimum wage standard has considered the level of living needs. This can be seen in the previous version of DLN that only regarded physical needs. The current version of DLN, on the other hand, also includes spiritual needs. The addition in the component of DLN and the increase in the quality of components becomes evident for the existing supports towards the level of necessities, started from the daruriyya to hajiiyya, and then tabsiniyya. This shows the change of law in line with the change of circumstances. This concept is in accordance with the concept of maslaha on legal changes.

Second, most of the DLN is in the area of daruriyya and hajiyya, only a few of them are tabsiniyya. Furthermore, the relevance exists between the necessity theory used as the basic guidance in determining the minimum wage and the necessity theory in the maqasid shariah. This relevance is shown by the existence of the material components that are able to support other components. Without those components, it is impossible to maintain the maqasid al shariah. This relevance is illustrated by the needs to support religious activities, such as the need for a sarong, mukena (prayer clothes for women), peci (head cap for men), and saving (tabungan) in the components of necessity.[]

\section{References}

Ali Ahmad, Al-Jurjawi, Hikmah Dibalik Hukum Islam. Jakarta: Mustaqim, 2003.

Al-Qardhawi, Yusuf, Fiqih Praktis bagi Kehidupan Modern. Kairo: Makabah Wabah, 1999.

Arief, Abd Salam. "Ushul Fiqh dalam Kajian Bisnis Kontemporer". In Ainurrafiq (ed.), Mazhab Jogja: Mengagas Paradigma Ushul Fiqh Kontemporer. Jogjakarta: ArRuzz. 2007. 
Asyhadie, Zaeni, Hukum Kerja, Hukum Ketenagakerjaan Bidang Hubungan Kerja. Jakarta: Rajawali Press, 2008.

Chaudhry, Muhammad Shaif, Sistem Ekonomi Islam, terj. Suherman Rosyidi Jakarta: Kencana, 2012.

Djazuli, A., Fiqh Siyasah. Bandung: Prenada Media, 2003.

Effendi, Satria, M. Zein. Ushul figh. Jakarta: Gramedia, 2004.

Gilarso, T., Pengantar Ilmu Ekonomi Mikro. Yogyakarta: Kanisius, 2003.

Jusmaliani, Pengelolaan Sumber Daya Insani. Jakarta: Bumi Aksara, 2011.

Martoyo, Susilo, Manajemen Sumber Daya Manusia. Yogyakarta: BPFE-Yogyakarta. 1990.

Mu'allim, Amir dan Yusdani. Konfigurasi Pemikiran Hukum Islam. Jogjakarta: UII Press. 1999.

Munawir, Ahmad Warson, Al-Munawir: Kamus Arab-Indonesia, cet. Ke-14. Surabaya: Pustaka Progressif, 1997.

Permenakertrans No: PER-01/MEN/1999 jo. Kepmenakertrans Nomor KEP. 226/ $\mathrm{MEN} / 2000$.

Permenakertrans No: PER-07/MEN/2013.

Purwadarminta, W.J.S., Kamus Umum Bahasa Indonesia, cet. Ke-5. Jakarta: Balai Pustaka, 1976.

Rahman, Afzalur, Doktrin Ekonomi Islam, alih bahasa,Soeroyo dan Nastangin, ed Sonhaji dan Hudiyanto. Yogyakarta: Dana Bhakti Wakaf, 1995.

Rochman, Ibnu. Hukum Islam dalam Perspektif Filsafat. Jogjakarta: Philosophy Press. 2001.

Ruky, Achmad S., Manajemen Penggajian dan Pengupahan untuk Karyawan Perusahaan, cet. Ke-2, Jakarta: Gramedia Pustaka Utama, 2002.

Sankaran, Kamala, "Labour laws in South Asia: The need for an inclusive approach", International Institute for Labour Studies. Geneva. 2007.

Sudirman, Antonius, Hati Nurani Hakim dan Putusannya, Suatu Pendekatan dari Prespektif Ilmu Hukum Perilaku (Behavioral Jurisprudence) Kasus Bismar Siregar. Bandung: Citra Aditya, 2007.

Sukirno, Sadono, Mikro Ekonomi Pengantar Teori, Edisi III. Jakarta: PT. Raja Grafindo Persada, 2005.

Suryandono, Widodo, Asas-asas Hukum Perburuhan, cet 2. Jakarta: Raja Grafindo Persada, 2014.

Syaifuddin, Muhammad, "Nasionalisasi Perusahaan Modal asing Ide Normatif Pengaturan Hukumnya dalam UU No. 25 Tahun 2007 dan Relevansinya dengan Konsep Negara Hukum Kesejahteraan Pancasila dalam UUD 1945”, Jurnal Simbur Cahaya, Vol. XVII No. 47 Januari 2012, Palembang: FH UNSRI

Zahrah, Abu, Tarikh al-Mazahib al-Islamiyyah fi as-Siyasah wa al-Aqaid wa Tarikh alMazahib al-Fighiyyah. Kairo: Dar al-Fikr. 1989.

Arifuddin Muda Harahap, Faculty of Sharia and Law, UIN Sumatra Utara, Indonesia. Email: arieff.muda@gmail.com 


\section{Mhliam}

AHKAM Jurnal Ilmu Syariah (ISSN: 1412-4734/E-ISSN: 2407-8646) is a periodical scientific journal published by Faculty of Sharia and Law of Syarif Hidayatullah State Islamic University Jakarta in collaboration with Indonesian Scientist and Sharia Scholar Association (HISSI). This journal specifically examines the science of sharia and obtains to present various results of current and eminence scientific research. The administrators receive articles as contributions Sharia and Islamic law disciplines from scientists, scholars, professionals, and researchers to be published and disseminated. The article will be situated in a selection mechanism, a review of proved reders, and a strict editing process. All articles published in this Journal are based on the views of the authors, but they do not represent the authors' journals or affiliated institutions.

AHKAM has been accredited based on the determination of Director General of Research Reinforcement and Development, Research, and Technology Ministry of Higher Education of Republic of Indonesia, No. 36/a/E/KPT/2016 (valid until 2021). 